\title{
ANTI-DIARRHEAL ACTIVITY OF AQUEOUS EXTRACT OF NAGASARI FLOWERS (Mesua ferrea L.) IN BALB/c MICE INDUCED BY Escherichia coli
}

\author{
Putu Monik Ananta Puspitarini $^{1 *}$, Iman Surya Pratama ${ }^{1}$, Bambang Fajar Suryadi ${ }^{2}$ \\ ${ }^{1}$ Pharmacy Programme, Faculty of Medicine, Mataram University, Majapahit Street No. 62, \\ Mataram 83115, Indonesia \\ ${ }^{2}$ Biology Programme, Faculty of Mathematics and Natural Science, Mataram University, \\ Majapahit Street No. 62, Mataram 83115, Indonesia
}

Received April 1, 2019; Accepted September 29, 2019

\begin{abstract}
Nagasari (Mesua ferrea L.) is empirically used for management for diarrhea in Nusa Tenggara Barat Province. However, the safety and efficacy of the nagasari have not been scientifically validated in an animal model. This study evaluated the activity of aqueous extract of the nagasari flowers in BALB/c mice induced by Escherichia coli to determine the effective dosage for anti-diarrheal effect. The aqueous extract of nagasari flowers $(0,4 \%(\mathrm{w} / \mathrm{v}) ; 0,8 \%(\mathrm{w} / \mathrm{v})$; and $1,6 \%(\mathrm{w} / \mathrm{v}))$ was administered orally to 3 groups of mice, whereas negative and positive control received aquadestilate and ciprofloxacin $130 \mathrm{mg} / \mathrm{kgBW}$ respectively orally once daily for 3 days. The frequency and consistency of feces were observed then the total colony of E. coli in feces was calculated using colony counter. Aqueous extract of nagasari flowers at concentration $1,6 \%$ showed significant inhibitory activity against Escherichia coli comparable with positive controls (diarrhea index 0,425; $>>0,05$ and total colony of E. coli in feces 100,2; p>0,05). This study provides scientific support for the traditional use of aqueous extract of nagasari flowers for the treatment of diarrheal diseases.
\end{abstract}

Keywords: anti-diarrheal; Aqueous extract; diarrhea index; Escherichia coli; nagasari.

\section{INTRODUCTION}

Diarrhea is an abnormal event that characterized by an increased in the frequency of defecate more than 3 times in 24 hours accompanied by the consistency of liquid stool (Kotloff et al., 2013).

Based on the Health Profile in Nusa Tenggara Barat (NTB) Province, the number of diarrhea patients had not experienced a significant decrease that is 158.993 and 175.361 in the year of 2015 and 2017 (Dinkes RI, 2015; 2018). Diarrhea can be caused by infectious agents such as bacteria, viruses and parasites, including Escherichia coli which includes Gram-negative bacteria.

Ciprofloxacin as the first-line in the treatment of diarrhea but has limitations such as side effects and resistance if used over a long period of time. In addition, this drug is a second-line treatment for tuberculosis
XDR/MDR (Extensively Drug

Resistance/Multi-Drug Resistance) so it must be used wisely (Raini, 2016). Herbal medicine is an option to be developed as anti-diarrhea.

Nagasari (Mesua ferrea L.) is one of the plant used traditionally as anti-diarrhea. In Dharma Usada Kuranta Bolong, states that part of the nagasari plant can be used as a diarrhea medicine (Listiawati et al., 2016). Mesua ferrea L. flowers is illustrated in Figure 1.

In vitro, the methanol extract of all parts of the nagasari flowers at concentration of 10 $\mu \mathrm{g} / \mathrm{mL}, 50 \mu \mathrm{g} / \mathrm{mL}$ and $>200 \mu \mathrm{g} / \mathrm{mL}$ showed the minimum inhibitory concentration values of $E$. coli of 2, 6 and 14 strains. Flavonoids mesuaferrone- $A$ and mesuaferrone- $B$ are through to acts in the antibacterial effect (Mazumder et al., 2004). 
In vivo scientific studies of nagasari flower extract as anti-diarrhea are still limited. Therefore, this study evaluated the activity of aqueous extract of the nagasari flowers in Balb/c mice induced diarrhea by $E$. coli in decreasing diarrhea index and total of $E$. coli colony in feces.

\section{METHODS}

\section{Collection and Identification of Flowers}

The fresh flowers of Mesua ferrea were collected from Lingsar, West Lombok in January 2018 and identified by Herbarium Bandungense SITH, Bandung Institute of Technology, Bandung No. 1493/11.CO2.2/PL/2018.

\section{Drying and Grinding}

The whole parts of flowers were washed, dried under shade for five days. The powdered of dry flowers were prepared with a mechanical grinder and passed through a 35mesh sieves. The powder was stored in a wellclosed container until the analysis was commenced.

\section{Extraction}

The powder of $M$. ferrea (nagasari) flowers were boiled in aquadestilate $(0,8 \% \mathrm{w} / \mathrm{v})$ during 15 minutes. The aqueous extract was stored properly (Hamad et al, 2017).

\section{Bacterial Preparation}

Escherichia coli ATCC 25922 strain was isolated from urine samples. This strain is part of the pathogen from the Yogyakarta Hall Health's Laboratory. The bacteria were grown on Nutrient Agar (NA) (Oxoid) (14 gram dehydrated NA in $500 \mathrm{~mL}$ aquadest) then transferred to the Eosin Methylene Blue Agar (EMBA) (Oxoid) (18,75 gram dehydrated EMBA in $500 \mathrm{~mL}$ aquadest (from Health Research and Development Installation of NTB Provincial Hospital) as selective media and Gram staining was carried out for the identification process accordance with the Bergey's Manual of Systematic Bacteriology (Whitman, 2010).

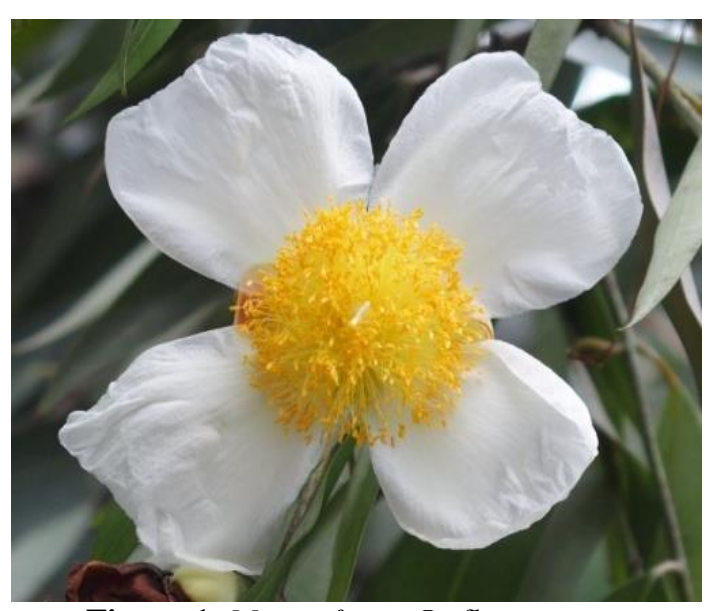

Figure 1. Mesua ferrea L. flowers

The bacteria were suspended in sterile physiological saline (0,9 gram $\mathrm{NaCl}$ (Merck) in $100 \mathrm{~mL}$ aquadest) until a concentration of approximately $10^{6} \mathrm{CFU} / \mathrm{mL}$ (Arief et al, 2010). The concentration of bacteria was calculated using Neubauer methods.

\section{Experimental Animals}

All procedures involving animals were approved by the Ethics Committee Faculty of Medicine of The Mataram University No. 91/UN18.8/ETIK/2018.

A total of $30 \mathrm{BALB} / \mathrm{c}$ mice weight between 25-40 $\mathrm{g}$ obtained from the Immunology Laboratory of Mataram University were used in this study. The mice were acclimatized under the standard environmental condition for 7 days. All mice had free access to food and destilate water adlibitum throughout the experimental period. The mice were divided into 6 groups randomly with 6 mice per group as follow: normal group (normal mice received destilate water $0,5 \mathrm{~mL}$ ), negative control group (diarrhea mice received destilate water $0,5 \mathrm{~mL}$ ), positive control group (diarrhea mice received ciprofloxacin 130 $\mathrm{mg} / \mathrm{kg}$ BW (13 mg ciprofloxacin (Hexpharm Jaya) powder in $5 \mathrm{~mL}$ aquadest)), and three group of treatment $(0,4 \% \mathrm{w} / \mathrm{v} ; 0,8 \% \mathrm{w} / \mathrm{v}$; $1,6 \% \mathrm{w} / \mathrm{v})$.

\section{Assessment of In-vivo Anti-diarrheal} Activity Escherichia coli induced diarrhea

Each mice was administrated orally with $100 \mu \mathrm{L}$ of $10^{6} \mathrm{CFU}$ of $E$. coli except the normal group to induced diarrhea (Astawan $e t$ 
al, 2009). After 30 minutes, each mouse is treated with the extract and ciprofloxacin.

All mice were treated every morning for 3 days. After the treatment, all mice were placed in individual cages, the floor of which was covered with filter paper. The number and consistency of stool were recorded for 6 hours.
The severity quantitatively of diarrhea was defined using three indexes (1) Loose Stool Incidence Rate / LSIR, (2) Average Loose Stool Grade / ALSG, (3) Diarrhea Index / DI and reduction in the total of colony of $E$. coli in feces (Hui et al, 2012; Han et al, 2014; Yu et al, 2017).

Table I. Effect of aqueous extract of M. ferrea (nagasari) flowers in decreasing total colony of Escherichia coli in feces

\begin{tabular}{|c|c|c|c|}
\hline & Group & Before treatment (CFU) & After treatment (CFU) \\
\hline $\mathrm{I}$ & E. coli + AEONF 0,4\% & $142,2 \pm 97,9$ & $155,6 \pm 96,9$ \\
\hline II & E. coli + AEONF $0,8 \%$ & $97,6 \pm 42,4$ & $41,4 \pm 31,2$ \\
\hline III & E. coli + AEONF $1,6 \%$ & $122,2 \pm 51,5$ & $22^{\text {a) }} \pm 15,9$ \\
\hline IV & E. coli + Cip & $\pm 34,7$ & $\pm 8,8$ \\
\hline V & E. coli + Destilated water & $128,2 \pm 51,4$ & $136,4 \pm 48,6$ \\
\hline VI & Destilated water & \pm 0 & $0^{\text {a) }}$ \\
\hline
\end{tabular}

Note. AEONF $=$ Aqueous extract of Nagasari flowers, Cip $=$ Ciprofloxacin, ${ }^{\text {a) }} \mathrm{p}>0,05$ comparable with positive controls.

Table II. Effect of aqueous extract of M. ferrea (nagasari) flowers in decreasing LSIR

\begin{tabular}{|c|c|c|c|}
\hline & Group & LSIR day 1 & LSIR day 3 \\
\hline I & E. coli + AEONF $0,4 \%$ & $0,161 \pm 0,06$ & $\pm 0,033$ \\
\hline II & E. coli + AEONF $0,8 \%$ & $0,273 \pm 0,202$ & $0,036^{\text {a) }} \pm 0,05$ \\
\hline III & E. coli + AEONF $1,6 \%$ & $0,355 \pm 0,25$ & \pm 0 \\
\hline IV & E. coli + Cip & $0,194 \pm 0,169$ & $\pm 0,089$ \\
\hline $\mathrm{V}$ & E. coli + Destilate water & $0,367 \pm 0,031$ & $\pm 0,159$ \\
\hline VI & Destilate water & \pm 0 & \pm 0 \\
\hline
\end{tabular}

Note. AEONF $=$ Aqueous extract of Nagasari flowers, Cip $=$ Ciprofloxacin, ${ }^{\text {a) }} \mathrm{p}>0,05$ comparable with positive controls.

Table III. Effect of aqueous extract of M. ferrea (nagasari) flowers in decreasing ALSG

\begin{tabular}{|c|c|c|c|}
\hline & Group & ALSG day 1 & ALSG day 3 \\
\hline I & E. coli + AEONF $0,4 \%$ & $1,04 \pm 0,089$ & $1,2 \pm 0,447$ \\
\hline II & E. coli + AEONF 0,8\% & $1 \pm 1$ & $0,8^{\text {a) }} \pm 1,095$ \\
\hline III & E. coli + AEONF 1,6\% & $1,131 \pm 0,144$ & $0^{\text {a) }} \pm 0$ \\
\hline IV & E. coli + Cip & $1,167 \pm 0,745$ & $0,267 \pm 0,596$ \\
\hline $\mathrm{V}$ & E. coli + Destilate water & $1,218 \pm 0,287$ & $1,506 \pm 0,389$ \\
\hline VI & Destilate water & \pm 0 & $0^{\text {a) }} \pm 0$ \\
\hline
\end{tabular}

Note. AEONF $=$ Aqueous extract of Nagasari flowers, Cip $=$ Ciprofloxacin, ${ }^{\text {a) }} \mathrm{p}>0,05$ comparable with positive controls. 
Table IV. Effect of aqueous extract of $M$. ferrea (nagasari) flowers in decreasing DI

\begin{tabular}{lllll}
\hline & \multicolumn{1}{c}{ Group } & \multicolumn{1}{c}{ DI day 1} & DI day 3 \\
\hline I & E. coli + AEONF 0,4\% & $0,170 \pm 0,074$ & $0,164 \pm 0,03$ \\
II & E. coli + AEONF 0,8\% & $0,273 \pm 0,202$ & $0,362 \pm 0,099$ \\
III & E. coli + AEONF 1,6\% & $0,425 \pm 0,33$ & $0,000^{\text {a) }} \pm 0$ \\
IV & E. coli + Cip & $0,306 \pm 0,251$ & $0,053 \pm 0$ \\
V & E. coli + Destilate water & $0,458 \pm 0,108$ & $0,638 \pm 0,713$ \\
VI & Destilate water & $0,000 \pm 0$ & $0,000^{\text {a) }} \pm 0$ \\
\hline
\end{tabular}

Note. AEONF $=$ Aqueous extract of Nagasari flowers, Cip $=$ Ciprofloxacin, ${ }^{\text {a) }} \mathrm{p}>0,05$ comparable with positive controls.

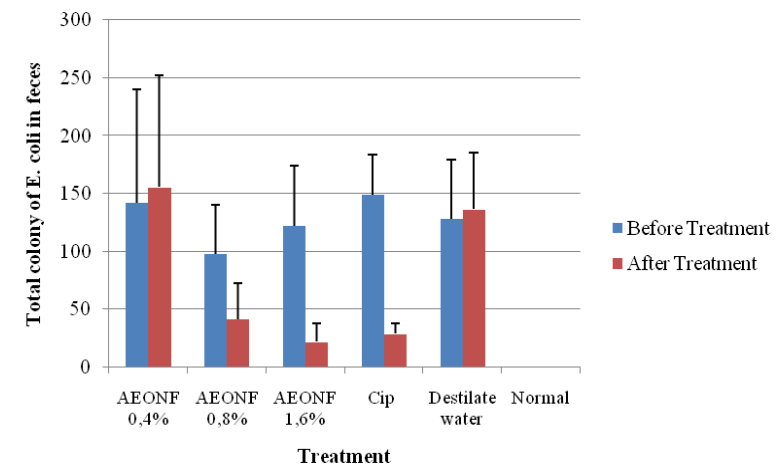

Figure 2: Effect of aqueous extract of Mesua ferrea in decreasing total colony of Escherichia coli in feces. $\mathrm{AEONF}=$ Aqueous extract of Nagasari flowers, $\mathrm{Cip}=$ Ciprofloxacin, a) $\mathrm{p}>0,05$ comparable with positive controls.

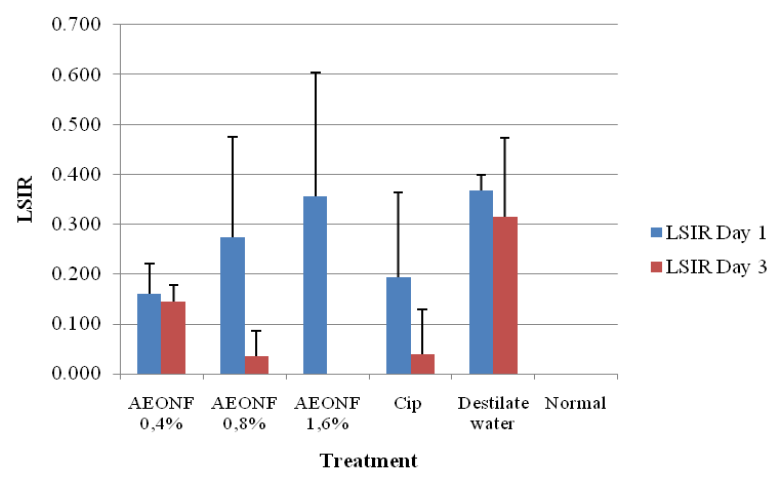

Figure 3: Effect of aqueous extract of Mesua ferrea in decreasing LSIR. AEONF $=$ Aqueous extract of Nagasari flowers, Cip $=$ Ciprofloxacin, ${ }^{a}$ p $>0,05$ comparable with positive controls.

\section{Data Collection and Analysis Samples Total colony of Escherichia coli in feces}

The fecal sample as much $50 \mathrm{mg}$ was placed in $2 \mathrm{~mL}$ Eppendorf tube, to which distilled water was added. The sample was diluted 4 times dilution. The fourth dilution $(100 \mu \mathrm{L})$ was fertilized by spread plate method on EMBA, then incubated at $37^{\circ} \mathrm{C}$ for 24 hours. Metallic green color on media showed a positive result of Escherichia coli in feces (Zhang et al, 2010; Analytic Jena, 2011).

Calculation of the total colony of Escherichia coli was carried out using a colony counter (Stuart ${ }^{\mathrm{TM}}$ Scientific colony counter Model SC5, AC/DC input 220 V AC). Mice infected if the total colony of bacteria in feces are $10^{5} \mathrm{CFU}$ (Newsome et al, 1987). Calculation formula for the total colony of bacteria in feces:

$$
\mathrm{N}=\frac{\Sigma C}{((1 \times n) \times d)}
$$

$\mathrm{N}$ : total of colonies $(\mathrm{mL} / \mathrm{g})$

$\mathrm{n}$ : total of plates in the first dilution;

$\mathrm{d}$ : the level of dilution obtained from the first cup calculated.

\section{Three indices of severity diarrhea}

The LSIR the ratio of the number of loose stools to the total stools within an animal. Loose stool grade describes the degree of loose stools, based on the diameter of the stool on the filter papers. The LSG was classified into four grades according to the diameter of loose stools; Grade $1(<1 \mathrm{~cm})$, Grade $2(1 \sim<2$ $\mathrm{cm})$, Grade $3(2 \sim 3 \mathrm{~cm})$ and Grade $4(>3 \mathrm{~cm})$. The ALSG is the ratio of the sum of the LSG of each loose stool to the total number of loose stools within each mice. The DI is the result of LSR multiplying ALSG (Hui et al, 2012; Han et al, 2014; Yu et al, 2017).

\section{Statistical analysis}

The data were analyzed by using Kruskal Wallis procedures, followed by Mann Whitney. Values of $\mathrm{p}<0,05$ were showed a significant difference between the effect of aqueous extract with positive controls statistically using SPSS 16 software. 


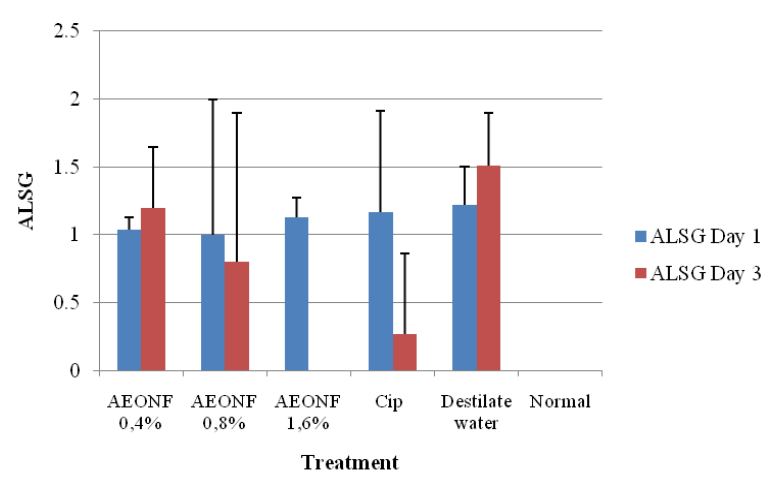

Figure 4: Effect of aqueous extract of Mesua ferrea in decreasing ALSG. AEONF = Aqueous extract of Nagasari flowers, Cip $=$ Ciprofloxacin, ${ }^{\text {a) }} \mathrm{p}>0,05$ comparable with positive controls.

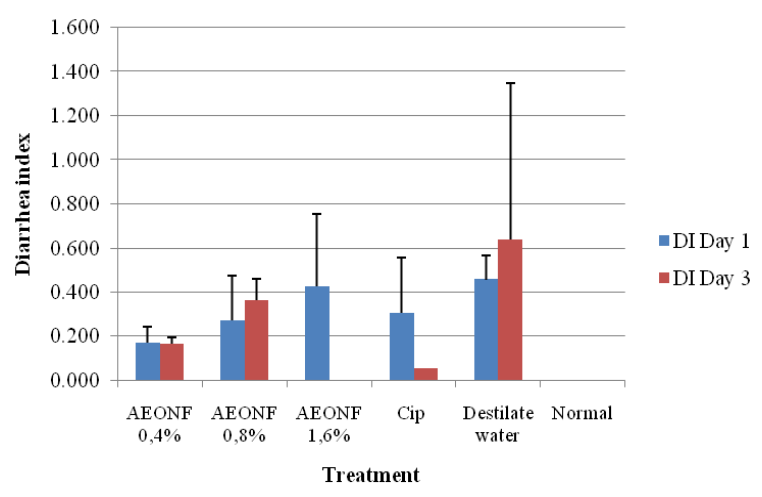

Figure 5: Effect of aqueous extract of Mesua ferrea in decreasing diarrhea index. $\mathrm{AEONF}=$ Aqueous extract of Nagasari flowers, Cip $=$ Ciprofloxacin, ${ }^{\text {a) }} \mathrm{p}>0,05$ comparable with positive controls.

\section{RESULTS AND DISCUSSION}

The AEONF (Table I and Figure 2) at concentration $1,6 \%$ showed the highest decreasing in the total colony of Escherichia coli compared to other concentration and the antibacterial effect compared to positive controls $(p>0,05)$.

The LSIR (Table II and Figure 3) describes the level of frequency of defecation. The LSIR did not differ between positive control and treatment group. The AEONF at concentration $1,6 \%$ showed the highest decreasing in the frequency of defecation compared to other concentration and the effect comparable with positive controls ( $p>0,05)$.

The ALSG (Table III and Figure 4) describes the level of consistency of feces, which is viewed from the size of the feces diameter on filter paper. The ALSG did not differ between positive control and treatment group (AEONF at concentration $0,8 \%$ and
$1,6 \%)$. AEONF at concentration $1,6 \%$ showed the highest decreasing in the consistency of feces compared to AEONF at concentration $0,8 \%$ and the effect comparable with positive controls $(\mathrm{p}>0,05)$.

Diarrhea index (Table IV and Figure 5) is an accumulation of LSIR and ALSG. The DI did not differ between positive control and treatment group. The AEONF at concentration $1,6 \%$ the highest decreasing in the values of DI significantly different with negative control. The AEONF at concentration 1,6\% showed the highest decreasing in the DI compared to other concentration and the effect comparable with positive controls ( $\mathrm{p}>0,05)$.

In this study, the AEONF showed antidiarrhea activity as evident from the inhibition of the increased diarrhea index induced by Escherichia coli.

Based on these four parameters, the AEONF at concentration 1,6\% showed the highest effectiveness as specific antidiarrheals. Mazumder et al (2004) have reported, nagasari flowers contain several flavonoid compounds. Allegedly, the content of flavonoids and tannins causes a decreasing in all four parameters.

Flavonoids can inhibit Gram-negative or Gram-positive bacteria. Alcohol groups in flavonoids can bind to peptidoglycan and lipopolysaccharide on the cell wall so that it will damage bacteria cell membranes. The Flavonoids have mechanisms such as ciprofloxacin by inhibiting the function of gyrase DNA by which interferes with the process of bacterial replication obtained (Jawetz et al, 2013; Mufti et al, 2017).

The role of tannin in adhesion cell and enzyme inactivating and disturb with protein transport in the inner layer of the cell. In addition, tannin bind to cell wall polypeptides which cause the formation of cell walls to be less than perfect. This cause osmotic pressure in cells so that bacterial cells die and lysis (Okuda, 2005; Smullen et al, 2007).

In this study, no signs of toxicity and mortality were found in mice so it was safe to use. Toxicity data on ethanol extracts of nagasari flowers doses of $500-2000 \mathrm{mg} / \mathrm{kgBW}$ also did not cause signs of acute toxicity in 
mice (Tiwari et al, 2012). However, further toxicity tests on the AEONF need to be carried out.

\section{CONCLUSION}

Aqueous extract of nagasari flowers at concentration $1,6 \%$ has the most effective specific anti-diarrheal activity indicated by the highest decreasing in the total colony of Escherichia coli and diarrhea index.

\section{REFERENCES}

Analytic Jena. 2012. innuPREP Stool DNA Kit. Analytic Jena AG. URL https://www.analytikjena.com/products/ki tsassaysreagents/kitsfordnarnaextraction/innuprep-stooldnakit/ (accessed 17.9.2019)

Arief, I.I., Jenie, B.S.L., Astawan, M., Witarto, A.B., 2010. Efektivitas Probiotik Lactobacillus plantarum $2 \mathrm{C} 12$ dan Lactobacillus acidophilus 2B4 sebagai Pencegah Diare pada Tikus Percobaan. Media Peternakan. 137-43.

Astawan, M., Wresdiyati, T., Arief, I. I., Febiyanti, D., 2011. Gambaran Hematologi Tikus Putih (Rattus norvegicus) yang Diinfeksi Escherichia coli Enteropatogenik dan diberikan Probiotik. Media Peternakan. 7-13.

Dinas Kesehatan Provinsi NTB. 2015. Profil Kesehatan Provinsi Nusa Tenggara Barat.

Hamad, A., Anggraeni, W., Hartanti, D., 2017. Potensi Infusa Jahe (Zingiber officinale R) sebagai Bahan Pengawet alami pada Tahu dan Daging Ayam Segar. Jurnal Aplikasi Teknologi Pangan. 6(4), 177183.

Han, X., Pang, Y., Liu, S., Tan, Z., Tang, S., Zhou, C., Wang, M., Xiao, W., 2014. Antidiarrhea and Antioxidant Activities of Honokiol Extract from Magnoliae officinalis Cortex in Mice. Tropical Journal of Pharmaceutical Research. 13(10), 1643-1651.
Hui, H., Chen, M., Li, G., Feng, H., Zang, L., Xi, Y., Dong, T., Zhou, X., 2013. Andrographolide Attenuates Senna- and Castor Oil-induced Diarrhea in Mice. Latin American Journal of Pharmacy. 32(8), 1113-1117.

Jawetz, E., Melnick, J., Adelberg. 2013. Medical Microbiology. Edisi ke-26. Jakarta: EGC.

Kementerian Kesehatan Republik Indonesia. 2018. Data dan Informasi Kesehatan Indonesia 2017. NTB: Kementerian Kesehatan Republik Indonesia. URL http://www.depkes.go.id/resources/download/pusdatin/profilkesehata nindonesia/DatadanInformasi_ProfilKesehatanIndonesia2018.p-df (acessed 18.11.2018).

Kotloff, K.L., Narato, J.P., Blackwelder, W.C., Nasrin, D., Farag, T.H., 2013. Burden and Aetiology of Diarrhoeal Disease in Infants and Young Children in Developing Countries (the Global Enteric Multicenter Study, GEMS): a Prospective, Case-Control Study. CrossMark. 382(9888), 209-222.

Listiawati, N.P., Juniawan, I.B.H., Anom, A.A.I.A., Sudarsana, I.W.G., Wibawa, I.G.J.S., 2016. Dharma Usadha Kuranta Bolong Klimosadha Sang Hyang Klimosadha.

Mazumder, R., Dasridar, S.G., Basu, S.P., Mazumder, A., Singh, S.K., 2004. Antibacterial Potentiality of Mesua ferrea Linn. Flowers. Phytotherapy Research. 18, 824-26.

Mufti, N., Bahar, E., Arisanti, D., 2017. Uji Daya Hambat Ekstrak Daun Sawo terhadap Bakteri Escherichia coli secara In Vitro. Jurnal Kesehatan Andalas. 6(2), 289-294.

Newsome, P.M., Burgess, M.N., Burgess, M.R., Coney, K.A., Goddard, jaM.E., Morris, J.A., 1987. A Model of Acute Infectious Neonatal Diarrhoea. Journal of Medical Microbiology. 23(1), 19-28. 